\title{
Nedsettende - og innafor?
} Lareres erfaringer med elevers bruk av stereotypier og fordomsuttrykk i klasserommet

\author{
Tonje Myrebøe \\ OsloMet - Storbyuniversitetet, Norge
}

\begin{abstract}
SAMMENDRAG
Denne artikkelen drøfter 20 læreres erfaringer med elevers bruk av stereotypier og fordomsuttrykk i ungdomsskolen og videregående skole. En sosialpsykologisk tilnærming åpner for å undersøke stereotypier og fordomsuttrykk slik lærerne beskriver at disse fenomenene ofte forstås som en integrert del av den sosiale interaksjonen i klasserommet. Jeg identifiserer og belyser mulige funksjoner disse ytringene kan ha i elevers sosiale samspill, og hvordan ulike kontekster og intensjoner spiller inn. Studien bidrar til økt kunnskap om kompleksitet og flytende grenser i klasserommet, med utgangspunkt i lærernes beskrivelser av stereotypier og fordomsuttrykk. Et sentralt funn i studien er lærernes beskrivelser av å bevege seg mellom ulike posisjoner i disse situasjonene. På den ene siden uttrykker de en forståelse for at elevenes ytringer ikke nødvendigvis uttrykker fordomsfulle holdninger eller negative intensjoner. På den andre siden beskriver de en usikkerhet og et ubehag, med bakgrunn i ytringenes tilknytning til rasistiske og diskriminerende praksiser, samt at de innebærer krenkelser av sårbare elever.
\end{abstract}

Nøkkelord: fordommer; sosiale dynamikker; sosiale normer; utdanning

Mottatt: Januar, 2020; Antatt: September, 2020; Publisert: Juni, 2021

\section{ABSTRACT \\ Disparaging - and acceptable? Teachers' experiences with students' use of stereotypes and prejudiced expressions}

In this article, I focus on 20 teachers' experiences of students' use of stereotypes and prejudiced expressions. Based on perspectives highlighting stereotype and prejudiced expressions as intertwined in social practices, I explore and discuss the teachers' narratives. The findings show a multitude of functions of, and dynamics in, students' use of stereotypes and prejudiced expressions. Thus, the study offers knowledge and a framework for understanding the complex nature of these phenomena as they appear to the teachers. An important finding from the analyses, is how the teachers describe their shifting positions in these situations. On the one hand, they express an

\footnotetext{
^Korrespondanse: Tonje Myrebøe, e-post: tonjem@oslomet.no

(C) 2021 Tonje Myrebøe. This is an Open Access article distributed under the terms of the Creative Commons Attribution 4.0 International License (https://creativecommons.org/licenses/by-nc/4.0/), allowing third parties to copy and redistribute the material in any medium or format and to remix, transform, and build upon the material for any purpose, even commercially, provided the original work is properly cited and states its license.

Citation: Tonje Myrebøe. «Nedsettende - og innafor? Lareres erfaringer med elevers bruk av stereotypier og fordomsuttrykk

$i$ klasserommet" Nordisk tidsskrift for pedagogikk og kritikk, Special issue: Forebygging av fordommer og gruppefientlighet, Vol. 7, 2021, pp. 210-223. http://dx.doi.org/10.23865/ntpk.v7.2141
} 
understanding of the students' utterances as not necessarily being expressions of prejudice or as intentionally harmful. On the other hand, they describe feelings of insecurity and discomfort tied to the students' utterances and their connection to racist and discriminatory practices, and that they can inflict harm on or violate vulnerable students.

Keywords: prejudice; social interaction; social norms; education

\section{Innledning}

Er det humor, kallenavn og en del av det sosiale samspillet? Eller er det krenkende og ekskluderende uttrykk for fordommer mot medelever? Eller kanskje begge deler? I intervjuer med lærere om forebygging av fordommer kom spørsmål som dette frem. Intervjuene handlet om lærernes erfaringer med elevers bruk av stereotypier og fordomsuttrykk i klasserommet, det vil si elevers bruk av generaliserende eller nedsettende ytringer som referer til gruppetilhørigheter tilknyttet etnisitet, religion, hudfarge, seksualitet, kjønn eller funksjonsnedsettelser. Et sentralt funn i denne studien er at lærerne beskriver en usikkerhet, samt et spekter av ulike fortolkningsmuligheter, med tanke på hva det er som foregår mellom elever i situasjoner hvor stereotypier og fordomsuttrykk veves inn som en del av det sosiale samspillet og dynamikkene.

Fordommer er et omstridt og komplekst fenomen, som gjerne opptrer gjennom subtile former og uttrykk det kan være vanskelig å fortolke eller få øye på. Gordon W. Allport (1958, s. 26) setter fordommer i sammenheng med menneskets tilbøyelighet til å kategorisere og generalisere sine omgivelser. Dette er en kognitiv prosess for å skape orden og oversikt i tilværelsen, som ikke nødvendigvis innebærer utelukkende negative generaliseringer av andre. Alt som høres ut som fordommer er heller ikke alltid emosjonelt forankrede holdninger. Fordommer kan brukes instrumentelt, og i samtaler kan negative generaliseringer «flyte» (Lenz \& Moldrheim, 2019, s. 39). På klasseromsnivå kan lærere møte stereotypier og fordomsuttrykk daglig, gjennom elevers ytringer eller i deres samspill. Dette er situasjoner hvor lærere må foreta raske avgjørelser som en del av deres daglige praksis. Hensikten med denne artikkelen er å bidra til økt kunnskap for å forstå hvilke funksjoner denne typen ytringer kan ha i klasserommet, samt å belyse læreres erfaringer med det de beskriver som et komplekst fenomen med rom for ulike fortolkningsmuligheter. Jeg har tatt utgangspunkt i følgende spørsmål: Hvordan kan vi forstå lareres fortolkninger av elevers bruk av stereotypier og fordomsuttrykk?

Studien er basert på intervjuer med lærere, og kan i så måte ikke fortelle noe om elevenes fordomsfulle holdninger i situasjonene som beskrives, men den kan gi innsikt i lærernes erfaringer med elevenes ytringer. Disse ytringene fremstår ikke nødvendigvis som negativt intenderte, men det er likevel situasjoner hvor lærerne forteller at de ved hjelp av ulike strategier setter grenser eller sanksjonerer elever. I denne artikkelen berører jeg imidlertid ikke disse strategiene, ettersom undersøkelsen er rettet mot ytringenes funksjoner og kompleksitet. 


\section{T. Myrebøe}

\section{Tidligere forskning og teoretiske perspektiver}

For å belyse lærernes beskrivelser og ulike fortolkninger av samspillet mellom elevene, har jeg valgt å ta i bruk begrepene fordomsuttrykk og stereotypier. Jeg vil her redegjøre for hva jeg legger i de to begrepene, og deretter presentere relevant forskning som et videre utgangspunkt for drøfting av det empiriske materialet.

Allport (1958, s. 12) legger til grunn at uttrykk for fordommer kan være en tilpasning til omgivelsenes normative rammer. Hva som regnes som fordomsfullt er avhengig av de involverte aktørene i den gitte konteksten. I denne artikkelen undersøker jeg fordomsuttrykk som en del av sosial praksis. En sosialpsykologisk tilnærming til fordommer som fenomen åpner for å undersøke fordomsuttrykk slik de fremstår som innvevd i hverdagen gjennom sosial interaksjon (Durrheim et al., 2016, s. 19-22). Lærere og elever, eller den enkelte elev, kan operere innenfor forskjellige sosiale normer, hvor det vil variere hvilke typer fordomsfulle ytringer man vil uttrykke eller ikke. Fordomsuttrykk kan derfor forstås som et fenomen med flytende grenser, hvor nedsettende ytringer som referer til gruppetilhørighet er avhengig av og tilpasses den gitte konteksten og hvem som er til stede.

Som nevnt innledningsvis, er kategorisering ifølge Allport (1958, s. 9) en naturlig del av menneskelig tenkning - en trang til å kategorisere menneskene man møter for å organisere informasjon i det daglige liv. En slik generalisering er ikke nødvendigvis en fordom, men en stereotypisering av andre som en del av den kognitive prosessen hvor den enkelte skaper orden og struktur i omgivelsene sine. Sosiale stereotypier kan forstås som en del av den sosiale prosessen hvor man justerer og tilpasser omgivelsene, med en tilbøyelighet til å vektlegge likhetene mellom mennesker man anser for å tilhøre sin egen gruppe (Moissinac, 2006, s. 609). Det er vanlig å søke tilhørighet til inn-grupper, et fellesskap hvor «vi-et» har en felles betydning, for eksempel gjennom felles religion, nasjonalitet, kjønn, familie eller vennekrets. Man søker også tilhørighet til referansegrupper, en inn-gruppe som er høyt verdsatt som man ønsker å bli inkludert i (Allport, 1958, s. 36-38).

Elevenes sosiale samspill i ungdomskolen og videregående skole er preget av identitetsarbeid. De skal finne frem til sin "personlige» måte å være ungdom og elev i skolen på. De skal forholde seg til skolens formelle og uformelle regler, og de må lære seg hva slags sosiale signaler og symboler som referer til ulike ungdomskulturer og identitetsprosjekter (Lyng, 2004, s. 35). Skoler i dag er også gjerne preget av et mangfold i elevgruppa, et begrep som kan referere til forskjellighet, variasjon og kompleksitet, og som gjerne knyttes til synlige forskjeller som fysisk funksjonalitet, kjønnsuttrykk som går på tvers av en tradisjonell tokjønnstenkning eller religiøse klesuttrykk (Røthing, 2020, s. 16). Innenfor de ulike skolekontekstene markerer elever sin egen identitet og gruppetilhørighet ved å vise frem en rekke holdninger til forskjellige medelever som symboliserer likhet til og nærhet med enkelte, og forskjell og distanse til andre (Lyng, 2004, s. 172). Grupperinger blant elever kan være basert på kombinasjoner av sosiale kategorier, med utgangspunkt i religion, hudfarge, sosiolekt, stedstilhørighet 
og holdninger (Eriksen, 2017, s. 138). Elevers uttrykte oppfatninger og opptredener kan slik også forstås som en måte å sende ut de rette sosiale signaler og meldinger om hvem de er, eller hvem de ønsker å være, samt å etablere vennskap og sosiale bånd. I dette samspillet mellom elevene kan bruk av stereotypier og fordomsuttrykk tilskrives negative eller positive betydninger - en ambivalens når det kommer til ytringens mening, avhengig av hvilke elever som er involvert og av relasjonen dem imellom (Ambjörnsson, 2004; Johannessen, 2020; Lundström, 2006; Moissinac, 2006; Phoenix et al., 2003; Slaatten et al., 2015).

Ungdommers språkbruk kan i tillegg gienspeile ulike lokale ungdomskulturer, og ses som uttrykk for identitetsutvikling gjennom interaksjon. Elevene forholder seg til uformelle sosiale regler og offisielle elevroller som tillater dem å vise frem sine svært forskjellige smaker, preferanser, subkulturelle tilhørigheter og symboler (Lyng, 2004, s. 177). Ungdommer justerer, tilpasser eller utfordrer tradisjonelle etniske og sosiale kategorier, samt språklige ideologier, på utallige måter (Eriksen, 2017; Jonsson, 2018; Røthing, 2017; Svendsen, 2015). Dette kommer gjerne til syne gjennom måten de uttrykker seg på i det daglige, gjennom egen stil og globale kulturelle uttrykk som hip hop eller andre identitetsmarkeringer (Svendsen, 2015, s. 5).

\section{Metode}

Artikkelen bygger på intervjuer med 20 lærere, hvorav 10 jobber i ungdomsskolen og 10 på videregående skole. Lærerne ble rekruttert ved personlig møte eller via bekjente, og noen igjen gjennom informanter (snøballmetoden). Noen av forskningsdeltakerne tok selv kontakt etter at jeg la ut informasjon om prosjektet på sosiale medier, og en del ble rekruttert via direkte forespørsel til skoler. Jeg ønsket å få en utvidet forståelse av hvordan lærere som profesjonsgruppe erfarer elevers bruk av stereotypier og fordomsuttrykk i skolen, og la til grunn at dette er fenomener som kan variere innenfor ulike kontekster og involverte aktører. På bakgrunn av dette har jeg intervjuet lærere som representerer en geografisk spredning fra alle landsdelene. Lærerne, 10 kvinner og 10 menn, representerer også forskjellige aldersgrupper og erfaringer fra skolen, både når det gjelder faglig bakgrunn og antall år i yrket. Denne variasjonen i utvalget av lærere reflekterer derfor ulike læreres perspektiver, og viser blant annet at både elevgrupper og skoleslag har betydning i lærernes møter med elevers nedsettende og generaliserende ytringer. Hver informant ble intervjuet én gang, og intervjuene varte fra 45 minutter til 2 timer. Alle intervjuene ble tatt opp på lydopptak og deretter transkribert. All identifiserende informasjon er anonymisert gjennom transkripsjonene, og informantene har blitt gitt nye navn av meg. Prosjektet ble godkjent av NSD i forkant av gjennomføringen av intervjuene.

Ved hjelp av en semistrukturert intervjuguide søkte jeg å stille spørsmål som åpner for lengre og beskrivende svar fra informantene. I intervjuguiden tok jeg 


\section{T. Myrebøe}

utgangspunkt i begrepene stereotypier og fordommer, og lærerne fortalte om opplevelser og hendelser de mente kunne knyttes til dette. Det ble tydelig gjennom intervjuene at både lærerne og jeg famlet en del for å finne hvilke begreper som var dekkende og kunne beskrive på en god måte deres erfaringer. Dette er et felt med mange overlappende termer og fenomener, og lærerne fortalte også om svært ulike hendelser når det gjaldt alvorlighetsgrad. Eksempler på begreper som ble brukt er fordommer, diskriminering, rasisme, mobbing og krenking. Usikkerheten omkring begrepsbruken belyser også at det kan være vanskelig å sette ord på sosiale dynamikker, hvilket diskusjonen i denne artikkelen illustrerer tydelig, samt at det kan kjennes ubehagelig å fortelle om det som kan oppfattes som negativ informasjon om elevene sine.

Allerede i intervjuprosessen ble det fremtredende at lærerne hadde mange fortolkninger av og refleksjoner omkring hvilke funksjoner stereotypier og fordomsuttrykk kan ha mellom elever. Disse refleksjonene fra lærerne ble fremhevet som et viktig tema gjennom en prosess hvor jeg opprettet tekstnære koder (ord og uttrykk) som beskrev avsnitt og utsnitt av de transkriberte intervjuene (Tjora, 2012, s. 179). I analysen har jeg videre søkt å identifisere og fortolke essensielle, men ikke nødvendigvis alle, sider ved datamaterialet, ledet av forskningsspørsmålet (Clarke \& Braun, 2017, s. 297). Informantenes erfaringer og beskrivelser presenteres gjennom direkte sitater fra intervjuene. Artikkelen inneholder gjengivelser av ord og uttrykk som er knyttet til nedsettende ytringer, rasisme og diskriminering. Elevers ordbruk er en sentral del av den empiriske analysen, og jeg presenterer derfor disse begrepene slik lærerne i denne studien forteller at de blir brukt av elever. For å understreke at disse ordene i denne sammenhengen kun gjengis med et analytisk formål, og er en ordbruk som jeg tar avstand til, har jeg valgt å markere dem gjennomgående i kursiv.

\section{Resultater og diskusjon}

I denne delen drøfter jeg hvordan vi kan forstå lærernes fortolkninger av elevers bruk av stereotypier og fordomsuttrykk. Intervjuene tegner et sammensatt bilde av overlappende ytringer og dynamikker i klasserommet, hvor ulike funksjoner og betydninger er tett sammenvevd. Jeg har valgt å diskutere lærernes fremstillinger og beskrivelser med utgangspunkt i tre adskilte tematiske deler for å gi en mest mulig oversiktlig fremstilling. I den første delen, «Ulike fortolkninger», undersøker jeg lærernes beskrivelser av en avstand mellom lærere og elever når det gjelder å ta i bruk stereotypier og fordomsuttrykk. I del to, «Skiftende betydninger», ser jeg nærmere på lærernes beskrivelser av hvordan elevers bruk av stereotypier og fordomsuttrykk kan skifte mellom å ha negative, nøytrale og positive betydninger, eksemplifisert ved elevers bruk av ordene homo og hore. Den tredje delen, "Å redefinere stereotypier", viser til lærernes fortellinger om elevers bruk av stereotypier og nedsettende generaliseringer som merkelapper på hverandre. 


\section{Ulike fortolkninger: «Det er jo et skjellsord»}

I dette avsnittet drøfter jeg lærernes beskrivelser av en avstand mellom elever og lærere når det gjelder bruk av stereotypier og fordomsuttrykk. Heidi, som jobber på en ungdomsskole, forteller følgende:

Ja, kanskje jeg mest oppfatter det at hvem som helst kan bli kalt for homo bare som en sånn i stedet for å si faen, på en måte, altså sånn at det meste blir helt dagligdags. Og det blir det jo til dels også når de bruker det om og om igjen og dette blir helt vanlig, så mister de jo nærmest sin betydning, ikke sant. Men, jeg har også faktisk hørt at elever blir kalt for jævla jøde.

Pål, en lærer med lang erfaring fra videregående skole, kommenterer elevers bruk av ordene hore og homo slik:

[d] et å bruke hore eller homo og sånt, var på mange måter et skjellsord, som de ikke la så veldig mye bak. $[\mathrm{M}]$ en for meg som da ikke bruker det som et daglig skjellsord, la jeg noe helt annet i det.

For Pål fremstår elevenes bruk av hore og homo som et hverdagslig "skjellsord", i likhet med Heidi som peker på homo som en erstatning for "faen". I begge disse sitatene viser lærerne til homo som en negativ generalisering, tilknyttet elevenes daglige språkbruk. Heidi og Påls beskrivelser kan vi forstå som det Ljung (1987, s. 14) kaller «sosial banning». Selv om banning er ansett for å være «ukorrekt» språkbruk, kan den også inngi «skjult prestisje» og for eksempel uttrykke tøffhet (Hasund, 2005, s. 23). Banningen trenger heller ikke være rettet mot noen, men snarere være reaksjoner på visse situasjoner og opptre i gitte kontekster (Ljung, 1987, s. 34).

Heidi forteller over at hun har «også faktisk hørt elever bli kalt for jævla jøde». Føde ble $\mathrm{i}$ intervjuene ofte løftet frem som et ord mange lærere erfarte var en del av den «sosiale banningen» som flyter mellom elevene, men også et ord de selv som lærere reagerte sterkt på. Anna, som har et annet opprinnelsesland enn Norge, forteller om da hun begynte å jobbe på en skole hvor elevene hyppig brukte uttrykket «din jøde» til hverandre:

Først skjønte jeg ikke ordet. Så jeg trodde «dinjøde» var ett ord, og det måtte bety noe annet enn «din jøde». Det var umulig for meg å tenke at man kunne bruke det. Og så, nei, okay, da er det «din jøde». Jeg var veldig, veldig usikker i begynnelsen. Men til slutt, jeg vet ikke, tre, fire, fem ganger var det bare sånn: Nei, det sier man ikke.

Anna er først usikker på hvilket uttrykk det er elevene bruker til hverandre. For henne er det utenkelig å bruke ordet jøde på denne måten, og hun tror derfor først at det er en språklig misforståelse. Rapporten Det som er jødisk (Døving \& Moe, 2014) er basert på intervjuer med eldre og yngre jøder i Norge, og peker nettopp på det at meningen og intensjonen bak bruken av jøde som skjellsord fortolkes ulikt mellom yngre og 


\section{T. Myrebøe}

eldre. Dette kan ses i sammenheng med nærheten eller avstanden til hendelsene i fortiden. Føde kan forstås som et uttrykk for underliggende, negative forestillinger om jøder, og være meningsbærende som skjellsord. Det kan imidlertid også forstås som ubevisste videreføringer av en språkbruk som ikke nødvendigvis spiller på utenforliggende meningssammenhenger. Intensjonen blir en annen, og ordet kan også oppfattes som en spøk avhengig av kontekst og aktører, og reflekterer slik en endring i kommunikasjonsform mellom unge og eldre (Døving \& Moe, 2014, s. 73).

Marte jobber på en videregående skole hvor hun forteller at det er ganske stor takhøyde når det gjelder forskjellighet i elevgruppa. Hun er selv i 40-årene, og beskriver elevene som mye mer tolerante nå enn tidligere, særlig når det kommer til å vise frem og anerkjenne ulike typer kjønnsuttrykk og seksuell orientering: «[d] et er jo kjempeuvant for min generasjon, tenker jeg, og helt selvsagt for mange av elevene mine». Hun forteller at ordet fag (slang/nedsettende for homo, homse) brukes i omtalen av hverandre blant en del av hennes elever. Selv anser hun fag for å være et skjellsord, mens elevene insisterer på at det blir brukt som et kjælenavn:

Fagen det er liksom, det tenker jo jeg med en gang, å herregud det er jo et skjellsord, er det greit liksom å [nøler]. Så har vi masse diskusjoner om det og de [elevene] insisterer veldig på at det er positivt da, lada. Men det der er jo kjempevanskelig.

Sitatet viser at Marte posisjonerer seg annerledes enn elevene når det kommer til bruken av ordet fag, og at hun også er bevisst at hun og elevene legger forskjellige betydninger i ordet (skjellsord og kjælenavn). Martes utsagn illustrerer hvordan aktører kan ha ulike oppfatninger om hvilke meninger og funksjoner et ord som fag kan ha, og hvordan ord i ulike situasjoner og kontekster kan skifte betydning. Marte knytter de ulike oppfatningene av uttrykket til en endring i toleransenivået hos ungdommer i dag. Selv om fag henspiller på en utsatt sosial kategori, noe Marte ser på som problematisk, fortolker hun det også slik at det i denne elevgruppa representerer en kommunikasjon hvor elevene ønsker å markere og fremvise toleranse, åpenhet og relasjon i elevgruppa, ved å utfordre en sosial kategori gjennom måten de bruker språket på (Svendsen, 2015, s. 5).

Sitatene fra intervjuene med Pål, Heidi, Anna og Marte, hvor de viser til ulike forståelser og bruk av stereotypier og fordomsuttrykk mellom elever og lærere, kan forstås som uttrykk for forskjellige sosiale normer hos partene. Durrheim og kollegaer (2016, s. 21) fremhever den sosiale og retoriske konteksten som betydningsfull for hvilke nedsettende eller generaliserende ytringer man tar i bruk, og definerer et «rom» mellom den enkeltes fordommer og omgivelsenes sosiale normer. I dette rommet foregår det en interaksjon mellom hvordan den enkelte vil fremstå for andre og de dynamiske sosiale prosessene hvor holdninger, normer og identiteter formes. Det normative og moralske rammeverket, den felles definisjonen for hva som er fordomsfullt, er gjerne en prosess som påvirkes mer av de involverte aktørene, heller enn de autoritative definisjonene. Grensene for hva som er akseptabelt er flytende, og de er 
avhengige av de involverte og konteksten. Hasund (2020, s. 42) fremhever også at ord alltid må ses i lys konteksten de blir brukt i. Definisjoner av ord kan diskuteres, og ords verdiladning eller markering av sosial gruppetilhørighet kan endre seg over tid. Røthing (2017, s. 139) peker på at hva som er akseptabel språkbruk kan utvikles og forhandles innad i en gruppe, og fungere som et lim som knytter individene i gruppa sammen. I et intervju med elever ved yrkesfaglig studieretning, beskriver elevene et fellesspråk som de bruker seg imellom, som de selv forstår er ment som humor, mens rektor og skolens ledelse reagerer negativt på det de oppfatter som elevenes «rasistiske språk». Skolens ledelse blir av elevene fremstilt som en motpart som ikke forstår at språkbruken er tull. Latter og humor i elevers samspill kan forstås på flere måter. Det kan være uttrykk for en glede over å bruke forbudte ord og stereotype identiteter på en nedsettende, men humoristisk måte i utenforståendes påsyn, en funksjon for å gjøre narr av sosial orden (Jonsson, 2018, s. 332), eller det kan styrke samhørigheten innad i en gruppe (Ljung, 1987, s. 14). Ubehaget som lærerne i intervjuene gjerne beskriver i møte med elevers generaliserende og nedsettende ytringer, kan ses i sammenheng med at det for lærerne er en tabubelagt språkbruk som også er knyttet til rasisme og diskriminering.

\section{Skiftende betydninger: «Og hore kan bli nesten som et statusord»}

Lærerne forteller at elevers bruk av stereotypier og fordomsuttrykk kan tilskrives både negative, nøytrale og positive betydninger, alt etter hvilke elever som er involvert og den relasjonen de har til hverandre. Dette kommer særlig godt frem i eksempler hvor de beskriver elevers ytringer rettet mot kjønn og seksuell orientering. Med utgangspunkt i lærernes fortolkninger og beskrivelser av elevers bruk av hore og homo, vil jeg drøfte hvordan vi kan forstå disse ytringenes skiftende betydninger.

Petter forteller at han opplever at hore noen ganger trekkes frem i konfliktsituasjoner: "Hvis to jenter kaller hverandre hore, så vet jeg at det ikke betyr at den ene påstår den andre selger sex for penger, det er første indikasjon på at dette eskalerer, her kommer det en konflikt». Heidi forklarer på den andre siden at hore også kan brukes som et uttrykk for positiv markering mellom elever: «Og hore kan bli nesten som et sånt statusord, fordi 'Ja hun er bare hora mi', eller 'Hun er bitchen min'». Petter og Heidis utsagn peker i samme retning som studiene til Ambjörnsson (2004), Lundström (2006) og Eriksen (2017). Ordet hore er gjennomsyret av ambivalens, med skiftende mening og betydning innenfor forskjellige relasjoner, kontekster og funksjoner. Hore er både et ord som det tas avstand til og som det kan lekes med, som en del av prosessen hvor feminine kjønnsposisjoner reguleres og differensieres. Ordets skiftende betydninger oppstår i et knutepunkt mellom ulike grupperinger av jenter, hvor sosial status knyttet til klasse og etnisitet fremstår som sentrale for ordets anvendelse (Ambjörnsson, 2004, s. 216). Jenters definering av andre jenter som hore kan også være en måte å regulere andre jenters seksualitet på (Lundström, 2006, s. 214), eller et verktøy for å markere grupper og posisjoner. Elevers beskrivelser og 


\section{T. Myrebøe}

benevninger av andre som hore, eller motsatt, fortellinger om hverandres seksualmoral, skaper kontraster som bidrar til å definere grupper og ulike rom for tilhørighet, eller utenforskap, tydeligere (Eriksen, 2017, s. 119, 120).

I tråd med forskning på feltet (Poteat et al., 2013; Slaatten et al., 2015) forteller mange av lærerne at de erfarer at det særlig er gutter som bruker homofobe uttrykk. Petter referer til de «tøffe gutta» når det kommer til bruk av ordet homo:

Jeg ser at for eksempel homo, blir brukt som et maktord av de tøffeste guttene i klassen. Ofte vel vitende om at flere av de andre i klassen har kanskje et uavklart forhold til hvem de er. Og det å da kunne definere seg selv som makthaver i en klasse ved å bruke ordet homo høyt og tydelig i en klassesituasjon, da har du på en måte undertrykt alle. Ikke sant, da ser du hvem som ler med deg og hvem som er med, og de som da ikke ler, de har du stilna.

Petter beskriver enkelte gutters måte å bruke homo på som et virkemiddel for å markere hierarkier og egen posisjon i klassen. Gjennom en diskursiv analyse av gutters samtaler finner Moissinac (2006, s. 617) at homofobe uttrykk i større grad brukes for å regulere maskulinitet enn homoseksualitet. I det dynamiske samspillet mellom guttene han observerte, fungerte det å bruke homofobe uttrykk om hverandre som en rask og effektiv måte for guttene å påberope seg maskulinitet. Gutters behov for å fremvise egen maskulinitet ved hjelp av homofobe ytringer, kan forstås som en av mange måter de kommuniserer en «naturlig heteroseksuell maskulinitet» på. På samme måte som jenters anvendelse av hore kan forstås som en måte å regulere og differensiere jenters kjønnsposisjoner, kan homofobe ytringer ha samme funksjoner for gutter, i at det gjenspeiler en oppfatning av heteroseksualitet som det naturlige (Nayak \& Kehily, 1996, s. 225, 226). Homofobe uttrykk kan også fungere som et selvforsvar mot frykten for å selv bli sett på som homofil og utsatt for homofob hets fra medelever (Phoenix et al., 2003, s. 192).

I mange av intervjuene blir det på den andre siden påpekt at homo er et ord som lett blir slengt ut mellom elevene i samtaler, for så å gjerne bli bortforklart som en spøk. Katrine forteller: «Da ser jeg for meg noen i den medieproduksjonsklassen, de ville vært noe sånn: 'Er du helt homo eller? Nei jeg bare kødda ass!'». Bruken av homo som et nedsettende "maktord", slik Petter forklarer det, er ikke alltid åpenbar i det daglige samspillet blant elevene, og betydningen av ordet er ofte uklar. Slaatten og kollegaer (2015) påpeker at nedsettende ordbruk relatert til homofili blant ungdommer kan oppleves som trakasserende, men også at det er vanlig å bruke denne typen ord mellom venner i tilsynelatende ufarlige settinger. Skillet mellom elevers erfaringer med homofob ordbruk som negativ eller positiv, relateres til de involvertes relasjoner i situasjonen (Slaatten et al., 2015, s. 713). I dette samspillet mellom elever ligger det, ifølge Johannessen (2020), en antatt oppfatning når det gjelder hva venner tåler og aksepterer av spøk og kommentarer. Denne typen kommentarer innebærer også en tvetydighet; de kan både referere til en manglende maskulinitet, eller forstås som uskyldige, vennskapelige kommentarer. 
Lærerne i denne studien trekker frem at når det foreligger en slik ambivalens knyttet til ordene som flyter mellom elevene, som eksemplifisert med bruk av ordene hore og homo, kan det være vanskelig å få oversikt over situasjonen og samspillet mellom elevene. Ingeborg jobber ved en videregående skole, og beskriver tvetydigheten slik:

Ja jeg vet ikke hva som er tull og hva som er alvor. Eller uansett om det er tull så syns jeg ikke det er greit. Fordi det, jeg tror det blir lagret i oss, det vi hører. Jeg tror de [utsatte elever] skjønner at det er tull. Men det spørs hvor mye du har å gå på i utgangspunktet. Hvor mye overskudd du har til å ta imot sånn.

Ingeborg setter her ord på hvor utfordrende det kan være å bedømme elevenes intensjoner og sårbarhet når nedsettende ytringer veves inn i humor og positivt samspill. Det er vanskelig å skulle kategorisere handlinger eller ytringer som aggressive eller krenkende når de ikke inneholder en synlig aggresjon, eller motreaksjon, i en situasjon hvor det er opp til den enkelte i hvilken grad ytringen oppleves som nedsettende. Stereotypier og fordomsuttrykks skiftende betydninger, knyttet til kontekst og ulike intensjoner eller funksjoner, gir rom for mange fortolkningsmuligheter for læreren. Et interessant spørsmål å stille videre, er på hvilke måter denne tvetydigheten virker inn på læreres grad av inngripen og deres håndtering av en slik generaliserende eller nedsettende ordbruk.

\section{A redefinere stereotypier: «De har liksom tatt eierskap til begrepet»}

Flere lærere forteller at kallenavn og merkelapper som elever bruker på hverandre kan knyttes til diskriminerende eller rasistiske ord og begreper. Krister har tidligere arbeidet på en videregående skole med en etnisk og religiøs heterogen elevgruppe. Han forteller at en del av elevene brukte «rasistiske uttrykk» som pakkis og neger i omtalen av hverandre:

Jeg har inntrykk av at de av afrikanske elevene som kaller hverandre neger de bruker det som omgangstone ja. De tar seg ikke nær av det. [M]en jeg har inntrykk av at hvis de på en måte er gode venner i utgangspunktet, så kunne de på en måte bruke det begrepet om hverandre da. Selv om ikke de hadde samme etniske bakgrunn. Så noen pakistanere kalte hverandre for eksempel for pakkis, som jo var nedsettende, det er jo ingen som bruker det lenger i det hele tatt. Men de hadde på en måte snudd det da, som man ser i afro-amerikanske miljøer, at de bruker nigger om hverandre. De har liksom tatt eierskap til begrepet.

Slik Krister forstår det, kan pakkis og neger brukes som nedsettende ytringer, men også for å markere vennskap, og gjerne på tvers av medelevers etniske bakgrunner. Disse ytringene, som er knyttet til nedsettende rasistisk og diskriminerende ordbruk, har med andre ord ulike funksjoner mellom elevene. De brukes blant annet for å markere tilhørighet til inn-grupper hvor vi-et har en felles betydning (Allport, 1958, s. 9), formet på kryss og tvers av gruppetilhørigheter, i ulike kombinasjoner av sosiale 


\section{T. Myrebøe}

kategorier som etnisk bakgrunn, religion eller hudfarge, i tråd med Eriksens studie (2017, s. 138).

Ungdommers måter å bruke språk på er et komplekst fenomen, og som vist i sitatet til Krister kan det basere seg på en overføring av stereotypier forbundet med etnisitet og hudfarge eller andre uttrykk for sosiale skiller og ulikheter. Jonsson (2018) observerte på en svensk videregående skole hvordan identiteter kan reproduseres og rokkes ved gjennom elevers humor og samspill. Ved hjelp av humor deltok elevene aktivt i konstruksjonen av den etniske Andre ("The ethnic Other») (Jonsson, 2018, s. 332, min oversettelse). De kunne le av en kategori som favnet dem selv og deres bakgrunner, samtidig som de rokket ved stereotypier ved hjelp av humor, og avdekket vilkårligheten og det absurde som ligger i generaliseringer basert på etnisitet, kjønn og hudfarge. Gjennom å leke med språket kan elever kommentere sin virkelighet og sine frustrasjoner, og forsøke å ta tilbake og redefinere stereotypier og nedsettende kommentarer (Roberts et al., 2008, s. 347). A ta i bruk en nedsettende benevnelse om seg selv, kan gi en opplevelse av kontroll og autoritet over egen posisjon, som videre svekker det tilknyttede stigmaet til den nedsettende benevnelsen (Galinsky et al., 2013, s. 2028).

På den andre siden, på tross av gode intensjoner og et ønske om å vende om på nedsettende og diskriminerende ords betydning, så er det like fullt vanskelig å ta eierskap til og redefinere begreper som er historisk og samfunnsmessig forankret med betydning og konnotasjoner (Roberts et al., 2008, s. 350). Mina, som jobber på en liten ungdomsskole, utdyper denne utfordringen for lærere gjennom et eksempel fra en periode hvor mange av guttene i klassen hennes brukte merkelappene neger og potet på hverandre:

Før jul for eksempel, da var det veldig mye neger. Og da gjorde de det til hverandre, selv om de var etnisk norske, og det gjorde de til de andre som var mørke i huden da. Og de gjorde det tilbake, og kalte de for poteter, ikke sant.

Mina beskriver disse situasjonene som en omgangsform mellom guttene hvor ingen har uttalt hverken til henne eller til noen av medelevene at de er ukomfortable med situasjonen, og hun observerer heller ikke tegn på aggresjon eller at noen elever blir krenket eller såret. Situasjonen fremstår også som uskyldig fordi elevene bruker kategorien neger på tvers av hudfarge, og bruker forskjellighetene dem imellom tilsynelatende uproblematisk. Uavhengig av elevenes intensjoner er det imidlertid grunn til å problematisere elevenes bruk av dette ordet på flere nivåer. Det er knyttet til en rasistisk tradisjon hvor fysiske trekk og hudfarge definerer og klassifiserer ulike mennesketyper, og danner grunnlag for hierarkisering av ulike mennesketyper (Bangstad \& Døving, 2015, s. 43). Rasialisert humor, hvor det tas i bruk diskriminerende stereotypier, kan i tillegg bidra til å fremme et inntrykk av stereotypier og fordomsuttrykk som legitime ytringer (Saucier et al., 2016, s. 81). Det er grunn til å stille spørsmål om hvorvidt elevers bruk av dette ordet kan ses i lys av at det er et både debattert og omdiskutert begrep, som enkelte vil forsvare med bakgrunn i dets historiske arv. 
Ordets konnotasjoner har endret seg over tid (Simonsen, 2008), og elevenes ytringer kan slik gjenspeile en ufarliggiøring av et rasistisk begrep.

Mina mener at ordbruken er uakseptabel, og setter grenser for den. Hun begrunner imidlertid også grensesettingen slik: «Men det var jo på en måte for å forhindre at de skulle bli støtt, og selv høre det [neger] hver dag i flere uker, og så til slutt så kommer det ut maks». Hun forstår det slik at elevene har forskjellige utgangspunkt for å ta imot denne merkelappen, i kraft av sine ulike bakgrunner og hudfarger. Dette innebærer at noen elever kan oppfatte kommentarene som negative; mottagerens oppfatning av budskapet trenger ikke være det samme som avsenderens intensjon. Humor som referer til rasistiske uttrykk er et fenomen som rommer ulike fortolkninger og mange muligheter for negative eller positive budskap til mottakeren. I kraft av å være en situasjon preget av humor, blir en mulig underforstått krenkelse tilslørt (Saucier et al., 2016, s. 81).

\section{Konklusjon}

Tidligere forskning har hovedsakelig undersøkt elevers bruk av stereotypier og fordomsuttrykk i skolen med fokus på elever. I denne studien har jeg undersøkt læreres erfaringer, og diskuterer deres fremstillinger og beskrivelser gjennom de tre tematiske delene: «Ulike fortolkninger», «Skiftende betydninger» og «Å redefinere stereotypier».

Elevenes bruk av stereotypier og fordomsuttrykk fremstår gjennom intervjuene med lærerne som tett sammenvevd med elevenes sosiale samspill. Det mest interessante funnet er, etter mitt syn, hvordan lærerne beveger seg mellom ulike posisjoner i disse situasjonene. Som en av lærerne uttrykte: «Du skal trå litt varsomt med å vite hva som er nedsettende og hva som på en måte er innafor». På den ene siden beskriver de en forståelse for at elevene bruker stereotypier og fordomsuttrykk på mange måter som ikke nødvendigvis reflekterer fordomsfulle holdninger eller negative intensjoner. På den andre siden uttrykker de en usikkerhet og et ubehag fordi stereotypier og fordomsuttrykk er tilknyttet rasistiske og diskriminerende praksiser og tradisjoner, og slik innebærer krenkelser av elever som er tilknyttet sårbare grupper. Situasjonene innebærer et både-og, en uklarhet det er vanskelig å sette ord på og begrepsfeste, og som tilsløres gjennom de sosiale dynamikkene.

Lærerne peker i tillegg på et skille mellom dem selv og elevene, hvor det er forskjellige normative og moralske rammeverk for hvilke nedsettende ytringer det er tillatt å ta i bruk. Ulike kontekster, intensjoner og funksjoner spiller også inn. Bruk av stereotypier og fordomsuttrykk kan forstås som et verktøy for elever til å utfordre en etablert sosial orden, eller justere og tilpasse ulike sosiale kategorier på. Lærerne erfarer at stereotypier og fordomsuttrykk gjennom elevenes samspill og relasjoner kan ha skiftende betydninger - de kan signalisere nærhet eller avstand til medelever, samt regulere og differensiere kjønnsposisjoner. Videre forskning bør undersøke på hvilke måter de komplekse sosiale dynamikkene som fordommer inngår $i$, slik denne studien belyser, virker inn på læreres handlingsrom og pedagogiske strategier i klasserommet. 


\section{T. Myrebøe}

\section{Forfatteromtale}

Tonje Myrebøe er ansatt ved OsloMet - storbyuniversitetet som stipendiat ved Fakultet for lærerutdanning og internasjonale studier, Institutt for internasjonale studier og tolkeutdanning, Seksjon for mangfoldsstudier.

\section{Referanser}

Allport, G. W. (1958). The nature of prejudice. Doubleday.

Ambjörnsson, F. (2004). I en klass för sig: genus, klass och sexualitet bland gymnasietjejer. Ordfront Förlag.

Bangstad, S. \& Døving, C. A. (2015). Hva er rasisme. Universitetsforlaget.

Clarke, V. \& Braun, V. (2017). Thematic analysis. The fournal of Positive Psychology, 12(3), 297-298.

Durrheim, K., Quayle, M. \& Dixon, J. (2016). The struggle for the nature of "prejudice": "Prejudice" expression as identity performance. Political Psychology, 37(1), 17-35.

Døving, C. A. \& Moe, V. (2014). «Det som er jødisk» - identiteter, historiebevissthet og erfaringer med antisemittisme. Senter for studier av Holocaust og livssynsminoriteter (HL-senteret). Hentet fra https://www.hlsenteret. no/aktuelt/publikasjoner/Rapport--Det-som-er-jodisk.pdf

Eriksen, I. M. (2017). De andres skole. Gruppedannelse og utenforskap $i$ den flerkulturelle skolen. Gyldendal Akademisk.

Galinsky, A. D., Wang, C. S., Whitson, J. A., Anicich, E. M., Hugenberg, K. \& Bodenhausen, G. V. (2013). The reappropriation of stigmatizing labels: The reciprocal relationship between power and self-labeling. Psychological Science, 24(10), 2020-2029.

Hasund, I. K. (2005). Fy farao! Om nestenbanning og andre kraftuttrykk. Cappelen.

Hasund, I. K. (2020). «æævla homo!» Om gruppebaserte skjellsord. I C. Lenz, P. Nustad \& S. Moldrheim (Red.), Dembra. Faglige perspektiver på demokrati og forebygging av gruppefiendtlighet $i$ skolen (Bd. 3, s. 30-45). Senter for studier av Holocaust og livssynsminoriteter (HL-senteret).

Johannessen, E. M. V. (under utgivelse). Blurred Lines: The Ambiguity of Disparaging Humor and Slurs in Norwegian High School Boys' Friendship Groups. YOUNG - Nordic Journal of Youth Research.

Jonsson, R. (2018). Swedes can't swear: Making fun at a multiethnic secondary school. Fournal of Language, Identity \& Education, 17(5), 320-335.

Lenz, C. \& Moldrheim, S. (2019). «Nulltoleranse» - fra lydighet til myndiggiøring. Hvordan møte krenkende atferd og fordomsfulle uttrykk i skolen. I C. Lenz, S. Moldrheim \& C. Gambert (Red.), Dembra. Faglige perspektiver på demokrati og forebygging av gruppefiendtlighet i skolen (Bd. 2, s. 34-49). Senter for studier av Holocaust og livssynsminoriteter (HL-senteret).

Ljung, M. (1987). Banning $i$ norsk, svensk og 18 andre språk. Universitetsforlaget.

Lundström, C. (2006). 'Okay, but we are not whores you know'. Latina girls navigating the boundaries of gender and ethnicity in Sweden. Young, 14(3), 203-218.

Lyng, S. T. (2004). Vere eller leere? Om elevroller, identitet og leering i ungdomsskolen. Universitetsforlaget.

Moissinac, L. (2006). Prejudicial expressions in defense of adolescent masculine identities in interaction. $A$ Fournal of Research, 55(9-10), 609-619.

Nayak, A. \& Kehily, M. J. (1996). Playing it straight: Masculinities, homophobias and schooling. Fournal of Gender Studies, 5(2), 211-230.

Phoenix, A., Frosh, S. \& Pattman, R. (2003). Producing contradictory masculine subject positions: Narratives of threat, homophobia and bullying in 11-14 year old boys. Fournal of Social Issues, 59(1), 179-195.

Poteat, P. V., DiGiovanni, C. \& Scheer, J. (2013). Predicting homophobic behavior among heterosexual youth: Domain general and sexual orientation-specific factors at the individual and contextual level. $A$ Multidisciplinary Research Publication, 42(3), 351-362.

Roberts, R. A., Bell, L. A. \& Murphy, B. (2008). Flipping the script: Analyzing youth talk about race and racism. Anthropology \& Education Quarterly, 39(3), 334-354.

Røthing, Å. (2017). Mangfoldskompetanse. Perspektiver på undervisning i yrkesfag. Cappelen Damm Akademisk.

Røthing, Å. (2020). Mangfoldskompetanse og kritisk tenkning: Perspektiver på undervisning. Cappelen Damm Akademisk. 
Saucier, D. A., O'Dea, C. J. \& Strain, M. L. (2016). The bad, the good, the misunderstood: The social effects of racial humor. Translational Issues in Psychological Science, 2(1), 75-85.

Simonsen, D. F. (2008). «Finn», «lapp» og «neger» - litt om sensitive ords liv og død. Språknytt (trykt utg.). Arg. 36(2008) nr 2, 1-6.

Slaatten, H., Anderssen, N. \& Hetland, J. (2015). Gay-related name-calling among Norwegian adolescents harmful and harmless. Scandinavian fournal of Psychology, 56(6), 708-716.

Svendsen, B. A. (2015). Language, youth and identity in the 21 st century: Content and continuations. I J. Nortier \& B. A. Svendsen (Red.), Language, youth and identity in the 21st century (s. 3-23). Cambridge University Press.

Tjora, A. H. (2012). Kvalitative forskningsmetoder i praksis. Gyldendal Akademisk. 